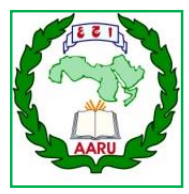

Arab Univ. J. Agric. Sci., Ain Shams Univ., Cairo, Egypt 28(2), 529-536, 2020

Website: http://ajs.journals.ekb.eq

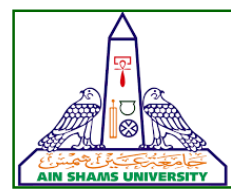

\title{
USE OF SOILLESS CULTURE TECHNIQUE IN THE PRODUCTION OF CHRYSANTHEMUM (Denderanthema grandiflora Ramat) CV."ZEMBLA"
}

\author{
Hadeer A.R. Mostafa ${ }^{1^{\star}}$, Hosni ${ }^{2}$ A.M., El-shinawy ${ }^{2}$ M.Z. and Hewidy ${ }^{2}$ M. \\ 1- Arid Lands Agricultural Graduate Studies and Research Institute, Ain Shams Univ., Shoubra \\ Elkeima, Cairo, Egypt \\ 2- Horticulture Dept., Fac. of Agric., Ain Shams Univ., P.O. Box 68, Hadayek Shoubra 11241, \\ Cairo, Egypt
}

*Corresponding author: deraahmed175@gmail.com

Received 19 May, 2020

Accepted 27 July, 2020

\section{ABSTRACT}

This research study was carried out during the two successive seasons of 2017/2018 and $2018 / 2019$ at the farm located within the vicinity of the Arid lands Agriculture graduated studies and Research Institute (ALARI), Shobra Elkheima, Qalyobia governorate, Egypt, under an unheated plastic-house (25 m length $\times 9$ m width $\times 3.5 \mathrm{~m}$ height). The experiments were laid out in a completely randomized design (CRD) with 3 replications, and the result data were subjected to analysis of variance (ANOVA). Chrysanthemum (Denderanthema grandiflora Ramat) cv. Zembla was employed in this research imported initially from DELIFLOR Company, in the Netherlands. Seedlings were planted in different substrate cultures to determine the most suitable local mixes for their cultivation and maximum production. Three of them were chosen from the local environment namely Water hyacinth, Palm fiber and Sugar-cane refuse in addition to Sawdust and Peat moss. The seedlings were planted into pots filled with eleven substrate culture mixes as follow: Water hyacinth $(\mathrm{WH}), \mathrm{WH}+$ peat moss (1:1), Palm fibers (PF), PF + Peat moss (1:1), Coarse sawdust (CS), CS + Peat moss (1:1), Fine sawdust (FS), FS + peat moss (1:1), Sugar-Cane refuse (SC), SC + Peat moss (1:1) and Peat moss. The results indicated that the substrate combination of $\mathrm{PF}+$ peat moss (1:1) and $\mathrm{WH}+$ peat moss (1:1) gave higher significant values when compared to other remaining substrate with regards to vegetative parameters, i.e. plant height, stem diameter, number of leaves per plant and greenness of leaves as SPAD reading
\end{abstract}

values. Also flower diameter exhibited a higher significant increase when $\mathrm{PF}+$ peat moss $(1: 1)+\mathrm{WH}+$ peat moss substrate combination was used compared to the other remaining substrates. Flower vase life also was influenced by the local substrate used in bringing up the cut-flowers and showed longer standing in the preservative solution when flowers were obtained from both of $\mathrm{WH}+$ peat moss (1:1) and Palm fiber + peat moss (1:1) compared to other substrate culture mixtures.

Keywords: Chrysanthemum, Substrate culture, Cut- flowers, Soilless culture, Water hyacinth, Palm fibers, Sawdust, Peat moss, Sugar-cane refuse.

\section{INTRODUCTION}

Flowers add a pleasure through illuminating colors and spreading fragrance (Manzoor et al 2001). Ornamental plants mostly exist in two forms, viz. pot plants and cut- flowers. Cut-flowers have a huge market worldwide. One of the important cut-flowers is chrysanthemum. Chrysanthemum belongs to the family Asteraceae. Chrysanthemum is very popular throughout the world. The shape of crown, beautiful colors and reasonable price make it dominant in most of the flower industries. Chrysanthemum production in soilless culture systems has been studied and developed for more than 30 years. In greenhouse production chrysanthemum is brought up through soilless cultivation by hydroponic culture besides soilless media coco-peat, perlite, etc. (Handreck and Black, 1994). Production of chrysanthe- 
mum requires an optimum mixture of macro, micronutrients compared with the use of soil several soilless systems and nutrient film techniques can lead to higher productivity (De Visser and Hendrix, 1987).

Soilless cultivation is becoming increasingly important as it is easier to control both the chemical and physical properties of the growth environment and substrate/medium can be selected having negligible chemical activity (Barbosa et al 2000).

(Verhagen, 1993) found chrysanthemum can be cultivated all year around in Coarse- grade peat as a substrate. Most chrysanthemum producers grow it in soilless mixes, which include peat, pearlite and vermiculite (Wang and pokorny, 1989). Simiralry, (Dutt and Sonawane, 2006) observed excellent performance of chrysanthemum (Chrysanthemum indicum L.) on a substrate containing cocoa-peat, compost, rice husk.

(Wright et al 2008) found that pine tree substrate for chrysanthemum production in greenhouse can be used as peat-lite medium.

The development of alternatives for peat substrates is necessary for the following reasons: (i) the resources of peat are limited, (ii) the pressure for using waste coming from human or industrial activities increases rapidly, and (iii) the economic necessity to use locally produced waste products is pressing (Szajdak et al 2016).

(Pizano, 2002) stated that in tropical and subtropical countries the increase of flower production in substrate culture had been slowed down because the high investment. New substrate components may offer better conditions for plant growth at the same time reduce production costs when compared with peat moss.

Therefore it was thought like a good idea to conduct experiments to find out the most available and suitable local mixture substrates in Egypt which would be more attractive and feasible for the production of cut-flower chrysanthemum.

\section{MATERIAL AND METHODS}

\section{Location and duration}

The experiments of this research study were conducted in the experimental location of the Aird lands Agriculture Research Institute (ALARI), Shobra EL Kheima, Qalyubiyya, Egypt in two successive seasons 2019 and 2020.

\section{Substrate culture types and treatments}

Six different types of substrates were chosen for this research study (water hyacinth, palm fibers, coarse sawdust, fine sawdust, peat moss, and sugar-cane refuse). All in all, eleven treatments were made up from the six substrates either separately or in combinations, as follow:

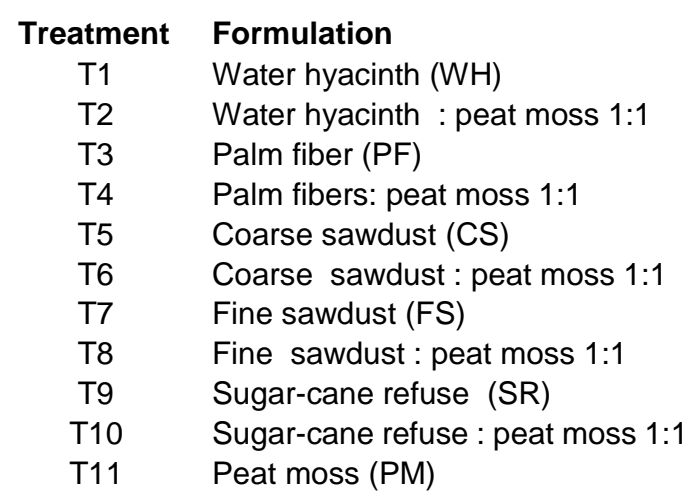

\section{Plant material and growing conditions}

Seedlings of chrysanthemum (Dendranthema grandiflora.Ramat) cv. Zembla were used in this research study. It was imported initially from DELIFLOR Company, Netherlands. The variety is strong with excellent quality stems. The flower color is white. The seedlings length was about $10 \mathrm{~cm}$ and contains 6-7 pairs of leaves. They were bought from Flora Mix Company. In the beginning of August, the 
(Denderanthema grandiflora Ramat) cv."Zembla"

chrysanthemum seedlings were initially cultivated in pots $(\mathrm{No} .12 \mathrm{~cm})$ filled with perlite: peat moss mix $(1: 2$ $\mathrm{v} / \mathrm{v})$ to help them form new roots. After three weeks the seedlings were transplanted in substrate culture in pots $(\mathrm{No} .25 \mathrm{~cm})$ after getting rid of the initial media by washing and put under a plastic-house. A pinching treatment was applied after two weeks from the transplanted to encourage side branching. Pots were spaced out at a distance of $30 \mathrm{~cm}$ between each other. Each plant was irrigated by a drip emitter $2 \mathrm{~L} /$ hour with nutrient solution three times a week for all substrate treatments except sawdust ones it was only two times a week. Long- day condition from incandescent lamps $(100 \mathrm{~W})$ was provided for plants between $6.00 \mathrm{pm}$ to $12.00 \mathrm{am}$ for eight weeks.

\section{Data Collected}

\section{Morphological characteristics}

- Plant height $(\mathrm{cm})$ using a graduated ruler.

- Leaf number/ plant.

- Stem and flower diameter $(\mathrm{cm})$ using a digital caliber.

- Flower vase life. Number of days from putting the flowers in a preservative solution until leaves turned to yellow color.

- Leaf greenness was estimated using a SPAD.

\section{Experimental Design and Statistical Analysis}

The experiment of each season was arranged in a completely randomized design with three replications for each treatment. Result data were subjected to analysis of variance (ANOVA). Data were statistically analyzed according to the separation among means using Duncan multiple range test (Duncan, 1955).

\section{RESULTS}

Influence of Substrate-culture Treatments on Vegetative Parameters

Data presented in Table (1) show the effect of that, plant height, stem diameter, number of leaves exhibited significant increases when plants were cultured in T2 and T4 substrates when compared to other substrates. Both substrate mixtures T2 and T4 gave the tallest plants in $1^{\text {st }}$ season $(55.25$ and $56.25 \mathrm{~cm}$ ) and exactly the same in the $2^{\text {nd }}$ season $(55.25$ and $56.25 \mathrm{~cm})$, respectively. Whereas, the shortest plants were obtained when plants were cultured in the T7 substrate $(13.05$ and $13.18 \mathrm{~cm}$, in respect order by season). As for stem diameter, T4 showed the largest stem diameter (5.47 and 4.60 $\mathrm{mm}$, in respect order by season) compared to other substrates. Meanwhile, the lowest stem diameter was obtained from T5 (3.32 and $3.20 \mathrm{~mm}$, in respect order by season). Leaf number/plant showed significant increase when plants were cultured on T2 and T4 in $1^{\text {st }}$ season (50.12 and 48.87 ) and exactly the same in the $2^{\text {nd }}$ season (50.12 and 48.87 ), respectively. Whereas, the lowest number of leaf/plant were obtained when plants were cultured in T7 substrate $(13.00$ and $13.0 \mathrm{~cm}$, in respect order by season).

\section{Influence of Substrate-culture Treatments on leaf chlorophyll (SPAD) and flower characters}

Data illustrated in Table (2) show the effect of different substrates on leaf chlorophyll color, flower diameter and vase life. Leaf chlorophyll color was increased when plants were cultured in T4 in the $1^{\text {st }}$ season (70.43) and in the $2^{\text {nd }}$ season $(70.83$ and 74.16), respectively. Whereas, the lowest leaf chlorophyll color values were obtained when plants were cultured in the T7 substrate (44.95 and 40.31) in respect order by season.

Flower diameter revealed significant increases when plants were cultured in T2 and T4 in the $1^{\text {st }}$ season ( 14.81 and $15.12 \mathrm{~cm}$ ) and in the $2^{\text {nd }}$ season $(15.00$ and $14.75 \mathrm{~cm})$, respectively. Whereas, the lowest number of leaves were obtained when plants were cultured in the T7 in the $1^{\text {st }}$ season and T8 in the $2^{\text {nd }}$ season (10.75 and $12.62 \mathrm{~cm}$ ) respectively.

As for vase life, cut-flowers resulted from substrate culture treatments exhibited a longer postharvest life period when obtained from T2 and T4 in the $1^{\text {st }}$ season (14.05 and 14.05 days) and in the $2^{\text {nd }}$ season (14.62 and 14.05 days), respectively. Whereas, the lowest vase life values were obtained when flower came from T5 (9.37 and 9.62) in respect order by season. 
Table 1. Effect of substrate-culture treatments on plant height, stem diameter and number of leaves of chrysanthemum (Denderanthema grandiflora Ramat).cv "Zembla"

\begin{tabular}{|c|c|c|c|c|c|c|}
\hline \multirow{2}{*}{ Substrate } & \multicolumn{2}{|c|}{$\begin{array}{c}\text { Plant height } \\
\text { (cm) }\end{array}$} & \multicolumn{2}{c|}{$\begin{array}{c}\text { Stem diameter } \\
(\mathbf{m m})\end{array}$} & \multicolumn{2}{c|}{ Number of leaves/plant } \\
\cline { 2 - 7 } & $\mathbf{1}^{\text {st }}$ season & $\mathbf{2}^{\text {nd }}$ season & $\mathbf{1}^{\text {st }}$ season & $\mathbf{2}^{\text {nd }}$ season & $\mathbf{1}^{\text {st }}$ season & $2^{\text {nd }}$ season \\
\hline T1 & $47.75 \mathrm{~b}$ & $47.75 \mathrm{~b}$ & $4.35 \mathrm{~b}$ & $3.62 \mathrm{e}$ & $43.87 \mathrm{~b}$ & $43.87 \mathrm{~b}$ \\
T2 & $55.25 \mathrm{a}$ & $55.25 \mathrm{a}$ & $4.43 \mathrm{~b}$ & $4.27 \mathrm{~b}$ & $50.12 \mathrm{a}$ & $50.12 \mathrm{a}$ \\
T3 & $47.87 \mathrm{~b}$ & $47.87 \mathrm{~b}$ & $4.39 \mathrm{~b}$ & $4.19 \mathrm{~b}$ & $44.07 \mathrm{~b}$ & $44.75 \mathrm{~b}$ \\
T4 & $56.25 \mathrm{a}$ & $56.25 \mathrm{a}$ & $5.47 \mathrm{a}$ & $4.60 \mathrm{a}$ & $48.87 \mathrm{a}$ & $48.87 \mathrm{a}$ \\
T5 & $14.00 \mathrm{fg}$ & $13.37 \mathrm{~d}$ & $3.32 \mathrm{c}$ & $3.20 \mathrm{~h}$ & $14.87 \mathrm{f}$ & $14.87 \mathrm{f}$ \\
T6 & $15.87 \mathrm{ef}$ & $15.31 \mathrm{~d}$ & $3.46 \mathrm{c}$ & $3.38 \mathrm{~g}$ & $23.62 \mathrm{~d}$ & $23.62 \mathrm{~d}$ \\
T7 & $13.05 \mathrm{~g}$ & $13.18 \mathrm{~d}$ & $3.36 \mathrm{c}$ & $3.35 \mathrm{~g}$ & $13.00 \mathrm{f}$ & $13.00 \mathrm{f}$ \\
T8 & $17.12 \mathrm{e}$ & $15.31 \mathrm{~d}$ & $3.56 \mathrm{c}$ & $3.52 \mathrm{ef}$ & $18.12 \mathrm{e}$ & $18.12 \mathrm{e}$ \\
T9 & $33.87 \mathrm{~d}$ & $14.37 \mathrm{~d}$ & $3.50 \mathrm{c}$ & $3.44 \mathrm{fg}$ & $22.12 \mathrm{~d}$ & $22.12 \mathrm{~d}$ \\
T10 & $47.37 \mathrm{~b}$ & $31.05 \mathrm{c}$ & $4.47 \mathrm{~b}$ & $4.01 \mathrm{c}$ & $27.62 \mathrm{c}$ & $27.62 \mathrm{c}$ \\
T11 & $39.12 \mathrm{c}$ & $46.93 \mathrm{~b}$ & $3.45 \mathrm{c}$ & $3.85 \mathrm{~d}$ & $44.56 \mathrm{~b}$ & $45.87 \mathrm{~b}$ \\
\hline
\end{tabular}

Means followed by the same letter in the column do not differ at the $5 \%$ probability by the duncan test. T1: Water hyacinth, T2: Water hyacinth + peat moss, T3: Palm fibers, T4: Palm fibers + peat moss, T5: Coarse sawdust, T6: Coarse sawdust + peat moss, T7: Fine sawdust, T8: Fine sawdust + peat moss, T9: Sugar-cane refuse, T10 Sugar-cane Refuse + peat moss, T11: Peat moss.

Table 2. Effect of substrate-culture treatments on leaf chlorophyll (SPAD), flower diameter and Vase life of chrysanthemum (Denderanthema grandiflora Ramat) cv."Zembla"

\begin{tabular}{|c|c|c|c|c|c|c|}
\hline \multirow{2}{*}{ Substrate } & \multicolumn{2}{|c|}{$\begin{array}{c}\text { Chlorophyll } \\
\text { (SPAD) }\end{array}$} & \multicolumn{2}{c|}{$\begin{array}{c}\text { Flower diameter } \\
\text { (cm) }\end{array}$} & \multicolumn{2}{c|}{$\begin{array}{c}\text { Vase life } \\
\text { (days) }\end{array}$} \\
\cline { 2 - 7 } & $\mathbf{1}^{\text {st }}$ season & $\mathbf{2}^{\text {nd }}$ season & $\mathbf{1}^{\text {st }}$ season & $\mathbf{2}^{\text {nd }}$ season & $\mathbf{1}^{\text {st }}$ season & $\mathbf{2}^{\text {nd }}$ season \\
\hline T1 & $54.45 \mathrm{de}$ & $56.23 \mathrm{~cd}$ & $14.31 \mathrm{bc}$ & $14.5 \mathrm{abc}$ & $13.00 \mathrm{c}$ & $13.00 \mathrm{c}$ \\
T2 & $64.66 \mathrm{ab}$ & $70.83 \mathrm{a}$ & $14.81 \mathrm{ab}$ & $15.00 \mathrm{a}$ & $14.05 \mathrm{a}$ & $14.62 \mathrm{a}$ \\
T3 & $58.26 \mathrm{bcd}$ & $59.00 \mathrm{bc}$ & $13.90 \mathrm{c}$ & $14.06 \mathrm{~cd}$ & $13.00 \mathrm{c}$ & $13.00 \mathrm{c}$ \\
T4 & $70.43 \mathrm{a}$ & $74.16 \mathrm{a}$ & $15.12 \mathrm{a}$ & $14.75 \mathrm{ab}$ & $14.05 \mathrm{a}$ & $14.05 \mathrm{a}$ \\
T5 & $45.03 \mathrm{f}$ & $45.16 \mathrm{f}$ & $12.56 \mathrm{e}$ & $12.81 \mathrm{fg}$ & $9.37 \mathrm{~g}$ & $9.62 \mathrm{~g}$ \\
T6 & $55.88 \mathrm{cde}$ & $48.73 \mathrm{ef}$ & $13.68 \mathrm{~cd}$ & $13.37 \mathrm{ef}$ & $11.00 \mathrm{e}$ & $11.05 \mathrm{e}$ \\
T7 & $44.95 \mathrm{f}$ & $40.31 \mathrm{~g}$ & $10.75 \mathrm{~g}$ & $10.05 \mathrm{~h}$ & $8.05 \mathrm{~h}$ & $8.37 \mathrm{~h}$ \\
T8 & $53.15 \mathrm{de}$ & $45.53 \mathrm{f}$ & $12.87 \mathrm{e}$ & $12.62 \mathrm{~g}$ & $10.00 \mathrm{f}$ & $10.00 \mathrm{~g}$ \\
T9 & $48.86 \mathrm{ef}$ & $49.04 \mathrm{e}$ & $13.68 \mathrm{~cd}$ & $11.06 \mathrm{~h}$ & $13.37 \mathrm{~b}$ & $10.05 \mathrm{f}$ \\
T10 & $54.35 \mathrm{de}$ & $55.01 \mathrm{~d}$ & $11.81 \mathrm{f}$ & $13.62 \mathrm{de}$ & $10.25 \mathrm{f}$ & $12.25 \mathrm{~d}$ \\
T11 & $62.56 \mathrm{bc}$ & $61.46 \mathrm{~b}$ & $13.18 \mathrm{de}$ & $14.25 \mathrm{bc}$ & $12.00 \mathrm{~d}$ & $13.62 \mathrm{~b}$ \\
\hline
\end{tabular}

Means followed by the same letter in the column do not differ at the $5 \%$ probability by the duncan test. T1: Water hyacinth, T2: Water hyacinth + peat moss, T3: Palm fibers, T4: Palm fibers + peat moss, T5: Coarse sawdust, T6: Coarse sawdust + peat moss, T7: Fine sawdust, T8: Fine sawdust + peat moss, T9: Sugar-cane refuse, T10 Sugar-cane Refuse + peat moss, T11: Peat moss. 


\section{Use of Soilless Culture Technique in the Production of Chrysanthemum (Denderanthema grandiflora Ramat) cv."Zembla"}

\section{DISCUSSION}

A growing medium should maintain a plant and supply it with water, nutrients, and the right conditions for exchanging gas in the root zone. The root system requires a sufficient amount of oxygen and free space between the substrate solid particles. Choosing a substrate is one of the decisive factors influencing cultivation of ornamental plants.

The principal constituent of a horticultural substrate is peat. Depending on its origin and the depth of a bed, the peat exhibits different physicochemical and biological properties (Szajdak et al 2016). Substrate with acceptable physical and chemical properties or suitable characteristics for a specific soilless substrate culture system could be prepared by mixing adequate proportions of the different particle size (Noguera et al 2003).

The choice of a medium component used depends on the availability of materials, cultivation methods, and the size and type of a container used for rooting (Szajdak et al 2016). The need to reduce the amount of imported materials for potting mixture is becoming essential. The most significant alternative found in some countries was coir dust resulted from coconuts by-products (Reddy, 2019). Stamps and Evans (1997) concluded that coir dust was an adequate substitute for sphagnum peat and could be used for growing $D$. maculate.

In this research study, PF + peat moss substrate followed by $\mathrm{WH}+$ peat moss substrate significant proved to be successful partial substitutes for pure peat moss, via simply substituting peat moss by $50 \%$ of above local materials, The physiochemical properties in palm and water hyacinth media were better than others in increasing growing indexes. The low amount of bulk density and high amount of porosity allowed plant roots to penetrate in the substrate more easily.

Contrariwise, both fine and coarse sawdust substrate gave the lowest value with all characteristics due to the high $\mathrm{C}: \mathrm{N}$ ratio and the high amount of bulk density, low amount of porosity.

From result data obtained herewith, it was clear that both substrate treatments, i.e. water hyacinth + peat moss and palm fibers + peat moss were superior in giving maximum positive results in all vegetative parameters measured ( plant height, flower diameter, number of leaves/plant and chlorophyll SPAD readings) in addition to extended vas life of cut-flowers of chrysanthemum cv."Zembla".
Most likely both local substrates, viz. water hyacinth and palm fibers when added to peat moss improved the overall physical structure of both substrate cultures, Accordingly, air spaces between particles of both substrates were larger around the root zone of chrysanthemum which struck the right balance for aeration and water holding capacity around the root zone of chrysanthemum cv."Zembla".

Besides, when peat moss was added to both water hyacinth and palm fibers substrates the $\mathrm{pH}$ of both substrates was lowered sufficiently in a favorable manner (refer to appendix 1). Definitely, this led to make nutrient elements around the root zone available for absorption by roots (Alam et al 1999). This was ultimately reflected on the wellbeing and healthy conditions of the final cut-flowers obtained from chrysanthemum cv. "Zembla".

In contrast, sawdust (both coarse and fine) as a substrate was inferior in all aspects of result data of chrysanthemum cv. "Zembla". Despite the fact that irrigation water was added less frequent ( two times weekly instead of three times for the rest of substrate culture treatments, still the water holding capacity of water was apparently high around the root zone with noticeable poor drainage of excess water. Undoubtedly, the roots of chrysanthemum cv. "Zembla" must have suffered greatly from less air in substrate cultures involving sawdust which led to less absorption of nutrient elements and in final poor performance.

Luckily enough, the two selected local substrates, namely water hyacinth and palm fiber, which gave advantageous and favorable results with chrysanthemum cv. "Zembla" are available in abundance in the Egyptian environment and in prices too. Using them to partially substitute peat moss would not only make us less dependent on an imported expensive commodity but also would reduce the final cost of substrate mixes used as culture media in the production of a lot of horticultural crops raised by soilless culture.

\section{REFERENCES}

Alam S.M., Naqvi S.S. and Ansari R. 1999. Impact of soil pH on Nutrient uptake: Handbook of plant and crop stress. Marcel Dekker, Inc, New York, pp. 51-60. 
Barbosa J.G., Kampf A.N., Martinez H.E., Koller O.C. and Bohnen H. 2000. Chrysanthemum cultivation in expanded clay. I. Effect of the nitrogen-phosphorus-potassium ratio in the nutrient solution. J. of Plant Nutrition, 23, 1327 1336.

De Visser A.J. and Hendrix A.T.M. 1987. Economic aspects of growing systems for years round chrysanthemums. Acta Horticulture 197, 111-114.

Duncan D.B. 1955. Multiple Range and Multiple F Test. Int. Biometric Society, 11(1), 1-42.

Dutt M. and Sonawane P.C. 2006. Nutrient uptake in chrysanthemum grown on various substrates. Indian J. of Horticulture 63, 66-69.

Handreck K.A. and Black N.D. 1994. Growing media for ornamental plants and turf. UNSW press. Sydney, Australia, 448 p.

Manzoor R. Shahid, Shaukat Ali. And Baluch, Mazhar-Ul-Haq. 2001. 'Economics of floriculture in Pakistan: A Case Study of Lahore Market'. Pakistan Economic and Social Review 39(2), 87-102.

Noguera P., Abad M., Puchades R., Maquieira A., and Noguera V. 2003. Influence of particle size on physical and chemical properties of coconut coir dust as container medium. Communications in Soil Science and Plant Analysis, 34(3-4), 593-605.
Pizano M. 2002. Alternatives to methyl bromide for use in cut-flower production. In Proceedings of international conference on alternatives to methyl bromide. The Remaining Challenges. In: Batchelor, T., Bolivar, J. (Ed.). European Commission, Brussels, pp. 233-237.

Reddy N. 2019. Agricultural Applications of Coir. In: Sustainable Applications of Coir and Other Coconut By-products. Springer, Cham., pp. 3154.

Stamps R.H. and Evans M.R. 1997. Growth of Dieffenbachia maculataCamille'in Growing Media Containing Sphagnum Peat or Coconut Coir Dust. HortScience, 32(5), 844-847.

Szajdak L.W., Styła K., Gaca W., Meysner T., Szczepański M. and Nowak J.S. 2016. The Importance of Horticultural Growing Media and Biochemical Processes. In: Szajdak L. (eds.) Bioactive Compounds in Agricultural Soils. Springer, Cham., pp. 287-312.

Verhagen J.B.G.M. 1993. Peat as a substrate for year round chrysanthemum growing. Acta Horticulture 342, 221-228.

Wang T. and Pokorny F. 1989. Pecan shells organic component of container potting media Hortscience 24, 75-78.

Wright R.D., Jackson B.E., Browder J.F. and Latimer J.G. 2008. Growth of chrysanthemum in pine tree substrate requires additional fertilizer. HortTechnology 18(1), 111-115. 
(Denderanthema grandiflora Ramat) cv."Zembla"

\section{Appendix (1)}

Chemical analysis of a sample of the experimental substrate-culture mixes used in the production of chrysanthemum cv. "Zembla"

\begin{tabular}{|c|c|c|c|c|c|c|}
\hline Sample & \multirow{2}{*}{ PH at 1:10 } & EC (dS/m) & \multicolumn{4}{|c|}{$\%$} \\
\cline { 4 - 7 } & & at 1:10 & O.C & N & P & K \\
\hline Water hyacinth & 8.24 & 0.73 & 19.20 & 1.25 & 0.26 & 0.47 \\
Water hyacinth + peat moss & 4.90 & 2.34 & 20.20 & 0.79 & 0.20 & 0.66 \\
Palm fiber & 7.09 & 6.38 & 20.60 & 1.01 & 0.25 & 0.89 \\
Palm fiber + peat moss & 5.58 & 0.73 & 20.60 & 0.48 & 0.05 & 0.05 \\
Coarse sawdust & 6.64 & 1.08 & 20.20 & 0.11 & 0.02 & 0.07 \\
Coarse sawdust + peat moss & 4.35 & 0.73 & 21.00 & 0.30 & 0.04 & 0.04 \\
Fine sawdust & 6.55 & 1.42 & 20.40 & 0.19 & 0.03 & 0.08 \\
Fine sawdust+ peat moss & 4.67 & 0.74 & 20.80 & 1.01 & 0.25 & 0.89 \\
Sugar-cane refuse & 7.16 & 2.30 & 21.00 & 0.95 & 0.40 & 0.34 \\
Sugar-cane refuse+ peat moss & 5.97 & 1.87 & 20.80 & 0.87 & 0.15 & 0.14 \\
Peat moss & 4.20 & 3.37 & 20.80 & 0.95 & 0.40 & 0.34 \\
\hline
\end{tabular}

Analysis was carried out by the lab of (ALARI), Ain Shams University 


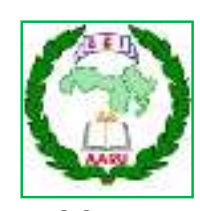

مجلة اتحاد الجامعات العربية للعلوم الزراعية، جامعة عين شمس، القاهرة، مصر مجلد(28)، عدد(2)، 536-529، 2020

\section{إستخدام تقنية الزراعة بدون تربة فى إنتاج نبات الأراولا (Denderanthem grandiflora Ramat) cv. "Zembla"}

هدير أحمد رأفت مصطفى1" - عبد العزيز محمد حسنى2 - محمد زكى الثناوى2 - محمد هويدى2 1- معهد الدراسات العليا والبحوث الزراعية بالمناطق القاحلة - جامعة عين شمس - شبرا الخيمة - القاهرة - مصر 2- قسم البساتين- كلية الزراعة - جامعة عين شمس - صندوق بريد 68 - حدائق شبرا 11241 - القاهرة - مصر

*Corresponding author: deraahmed175@gmail.com

بيتموس. أوضحت النتائج أن بيئة ألياف النخيل + بيتموس (1:1) وبيئة ورد النيل + بيتموس النيان (1:1) قد النداف

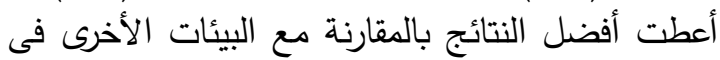

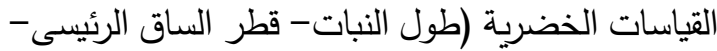

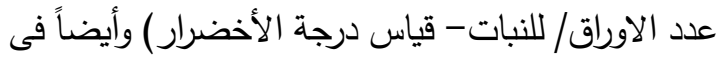
القياسات الزهرية (قطر الزهرة) أدت بيئة ألياف النخيل) والنيا في

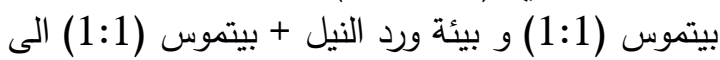

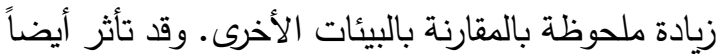

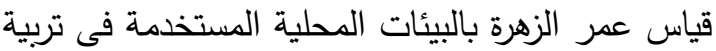

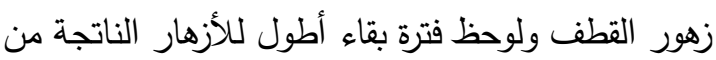
كلاً من بيئة ورد النيل + بيتموس و وبئة بئة ألياف النخيل

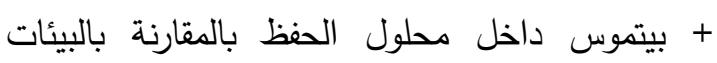

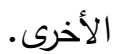

الكلمات المفتاحية: الأراولا، البيئات البديلة، زهور

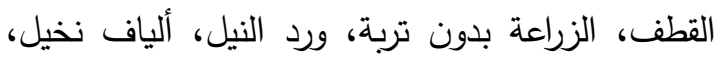
نشارة خشب، بيتموس، مخلفات قصب الزرون السكر

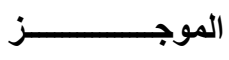

أجريت هذة الدراسة خلال عامين 2017/2018 و2018/2019 فى المزرعة الواقعه فى معهد الدراسات العليا والبحوث الزراعية بالمناطق القاحلة، شبرا الخيمة، التهات

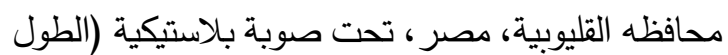

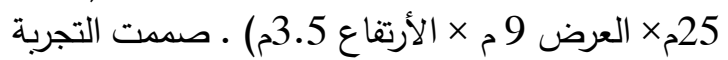

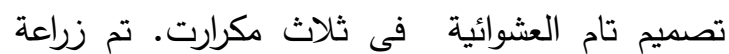
الشتلات فى عدة بيئات مختلفة لتحديد أنسب بيئة محلية

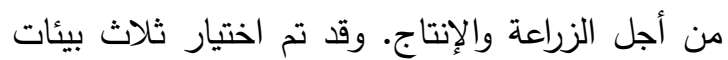

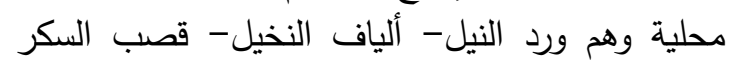

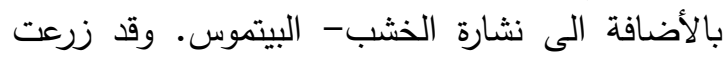
الشتلات داخل أصص (25سم) فى أحد عشره بيئة وهما

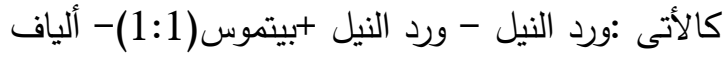
نخيل- ألياف النخيل +بيتموس(1:1)- نشارة خشب الني خشنة + نشارة خشب خشنة + بيتموس(1:1)- نشارة

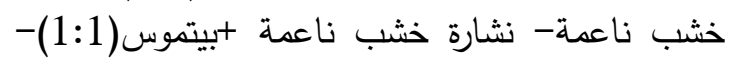
قصب السكر - قصب السكر + بيتموس(1:1) + 